Scientia Marina 74(1)

March 2010, 65-76, Barcelona (Spain)

ISSN: 0214-8358

doi: $10.3989 /$ scimar.2010.74n1065

\title{
Boat seines in Greece: Landings profiles and identification of potential métiers
}

\author{
STELIOS KATSANEVAKIS, CHRISTOS D. MARAVELIAS, VASSILIKI \\ VASSILOPOULOU and JOHN HARALABOUS
}

Institute of Marine Biological Resources, Hellenic Centre for Marine Research, 46.7 km Athens-Sounio, P.O. Box 712, 19013 Anavyssos, Attica, Greece. E-mail: skatsan@ath.hcmr.gr or stelios@katsanevakis.com

\begin{abstract}
SUMMARY: Although boat seines have a significant share in the total fish landings in Greece, there is little information on boat seine fisheries. The present study aims to identify boat seine métiers on a national level and contribute to a better understanding of their operation in Greece. We used boat seine landings data collected from a large number of ports in the Aegean and east Ionian Sea between 2002 and 2006. The landings profiles were grouped with a two-step procedure: the first step involved a factorial analysis of the log-transformed landings profiles, and the second step was a classification of the factorial coordinates (hierarchical agglomerative clustering). Six métiers were identified in the Aegean Sea, and three in the Ionian Sea. The 'picarel-bogue' métier was the most important in both seas, accounting for $54 \%$ and $88 \%$ of the fishing trips of the sample in the Aegean and Ionian Seas respectively. Apart from picarel and bogue, other important target species were red mullet, European squid, common pandora, chub mackerel, and European pilchard. Varying spatial (within the Aegean and Ionian Seas) and seasonal patterns were evident for the identified métiers.
\end{abstract}

Keywords: boat seine, Greece, landings profiles, métiers, small-scale fisheries, target species.

RESUMEN:ElbolicheENGRECIA:PeRFILESDEDESCARGaSEIDENTIFICACIóndEPOTENCIALESARTESMENORES.-Aunquelaflota de boliche contribuya en una cantidad significativa en las descargas totales de pescado en Grecia, la información que trata de la pesca con boliche es escasa. El presente estudio pretende identificar el arte (métier) del boliche en un nivel nacional y contribuir a una mejor comprensión de su operación en Grecia. Se han utilizado los datos de las descargas de la pesca con boliche, recogidos entre 2002 y 2006 en un gran número de puertos en la costa del Mar Egeo y Mar Jónico oriental. Los perfiles de las descargas fueron agrupados siguiendo un procedimiento en dos etapas: el primer paso consistió en un análisis factorial de los perfiles de descargas transformados logarítmicamente, y el segundo paso en una clasificación de las coordenadas factoriales (agrupamiento aglomerativo jerárquico). Se identificaron seis artes menores en el Mar Egeo, y tres en el mar Jónico. El arte menor "caramel-boga" ha sido el principal en ambos mares, alcanzándose valores del 54\% y del 88\% respecto al número total de las jornadas de pesca muestreadas en el Mar Egeo y Mar Jónico respectivamente. Aparte de caramel y boga, otras especies objetivo de importancia fueron los salmonetes, el calamar, la breca, el estorino y la sardina. Los artes menores identificados han mostrado unos patrones espaciales (dentro de ambos Mar Egeo y Mar Ionio) y estacionales.

Palabras claves: boliche, Grecia, perfiles de descargas, artes menores, pesca a pequeña escala, especies objetivo.

\section{INTRODUCTION}

Fishery management advice has traditionally been given on a stock-by-stock (or single-species) basis. However, conventional single-species fishery management has long been recognized as potentially problematic, especially in multi-species multi-fleet fisheries (Vinther et al., 2004). In these fisheries, more than one species is caught in the same area due to the underlying biocommunity structure, and different fleets exploit the same stocks simultaneously or sequentially, catching different proportions 
of the various species (Pelletier and Ferraris, 2000). As the species are not exploited independently due to the technical interactions of fishing practices, managerial guidelines for one stock unavoidably affect the management of all other target (and nontarget) stocks. Thus, to give management advice for mixed fisheries, it is more practical and effective if fleet-based or fishery-based approaches are used to supplement stock-based analyses. To provide multispecies multi-fisheries advice, fisheries scientists have to better understand the behaviour of fishers and assess the flexibility of fishing practices, which may vary depending on market conditions, the season, managerial restrictions, or the skipper's empirical knowledge (Hilborn and Ledbetter, 1985; Pelletier and Ferraris, 2000; Marchal et al., 2006). Each fishing practice is likely to impact exploited stocks in a particular way, and to assess the relationship between the total fishing effort of the fleet and the resulting fishing mortalities of the exploited stocks, a separate evaluation for each fishing practice is necessary (Pelletier and Ferraris, 2000). A starting point would be to identify fishing practices for every fleet segment in the fishery.

A first step towards defining fishing practices is to reduce the description of the variety of fishing trips to a single categorical variable that summarizes its main characteristics, i.e. the gear used, the fishing ground, and the target species (Pelletier and Ferraris, 2000; Ulrich and Andersen, 2004). This kind of variable has been referred to in the literature as "métier", "fishery", "directed fishery", "fishery management unit", "fishing trip type", "fishing strategy", and "fishing tactic" (Pelletier and Ferraris, 2000 and literature therein; Ulrich et al., 2001; Pech et al., 2001; Silva et al., 2002; Maynou et al., 2003; Ulrich and Andersen, 2004; Jiménez et al., 2004). We use the term "métier" in the present study.

Small-scale fisheries are quite an important part of the fishing sector all over the Mediterranean Sea. In Greece, small-scale fisheries are of particular societal and economic importance as their catches represent $47 \%$ of the production of Greek fisheries and $54 \%$ of the market income (Tzanatos et al., 2005). However, despite the high significance of small-scale fisheries in Greece, there is no national identification of métiers. A first attempt to identify the métiers of small-scale fisheries (including boat seines), based on questionnaires, was carried out by Tzanatos et al. (2005) in 9 of the 40 coastal prefectures of Greece. Tzanatos et al. (2006) identified the main small-scale métiers practiced in the Patraikos Gulf, using a sample of landings data from five ports, but did not include boat seines in the analysis. The boat seine is the most dynamic and productive fishing gear operated by the small-scale fisheries in Greece. Boat seines target small fish such as picarel (Spicara smaris), bogue (Boops boops), red mullet (Mullus barbatus), sardine (Sardina pilchardus), and squid (Loligo vulgaris). The aim of this study was to group landings profiles and to identify potential boat seine métiers, based on a large sample of landings records from all over Greece. The identification of métiers is potentially useful for mixed fisheries management, to understand the spatio-temporal patterns of fishing allocation, and to improve the design of stratified data collection in order to make better estimates of species-specific production.

\section{MATERIALS ANS METHODS}

\section{Study area, gear and fleet description}

The study area consisted of all Greek territorial coastal waters, i.e. most of the Aegean Sea, including the island of Crete, (i.e. GFSM 37.3.1, GSAs 22 and 23) and the eastern Ionian Sea (i.e. GFCM 37.2.2, GSA 20) (Fig. 1). The Aegean Sea has a long coastline $(\sim 16000 \mathrm{~km})$, complex bathymetry, generally narrow continental shelf, and many small islands (more than 2500). The Greek part of the Ionian Sea is characterized by a narrower continental shelf than the Aegean Sea, and also has the deep Hellenic Trench, which lies along the western and southwestern Hellenic coast and the islands of the Cretan Arc. Both the Aegean and the Ionian offshore waters are oligotrophic, while most coastal areas are mesotrophic (Gotsis-Skretas and Ignatiades, 2005; Siokou-Frangou et al., 2005). The Aegean Sea was divided into five sub-areas (north Aegean, south Aegean, Evvoikos Gulf, Argosaronikos Gulf and Pagassitikos Gulf) and the Ionian Sea into three subareas (central-south Ionian, north Ionian, Korinthiakos Gulf), based on their distinctive characteristics (Fig. 1).

A fleet of 17920 vessels operates in the Greek Seas, which represents approximately $45 \%$ of the total number of EU fishing vessels in the Mediterranean. The majority of vessels $(94.0 \%)$ have a length $<12 \mathrm{~m}$, and only $1.2 \%$ of the vessels have lengths $>24 \mathrm{~m}$. Among these vessels, a total of 362 (as of 


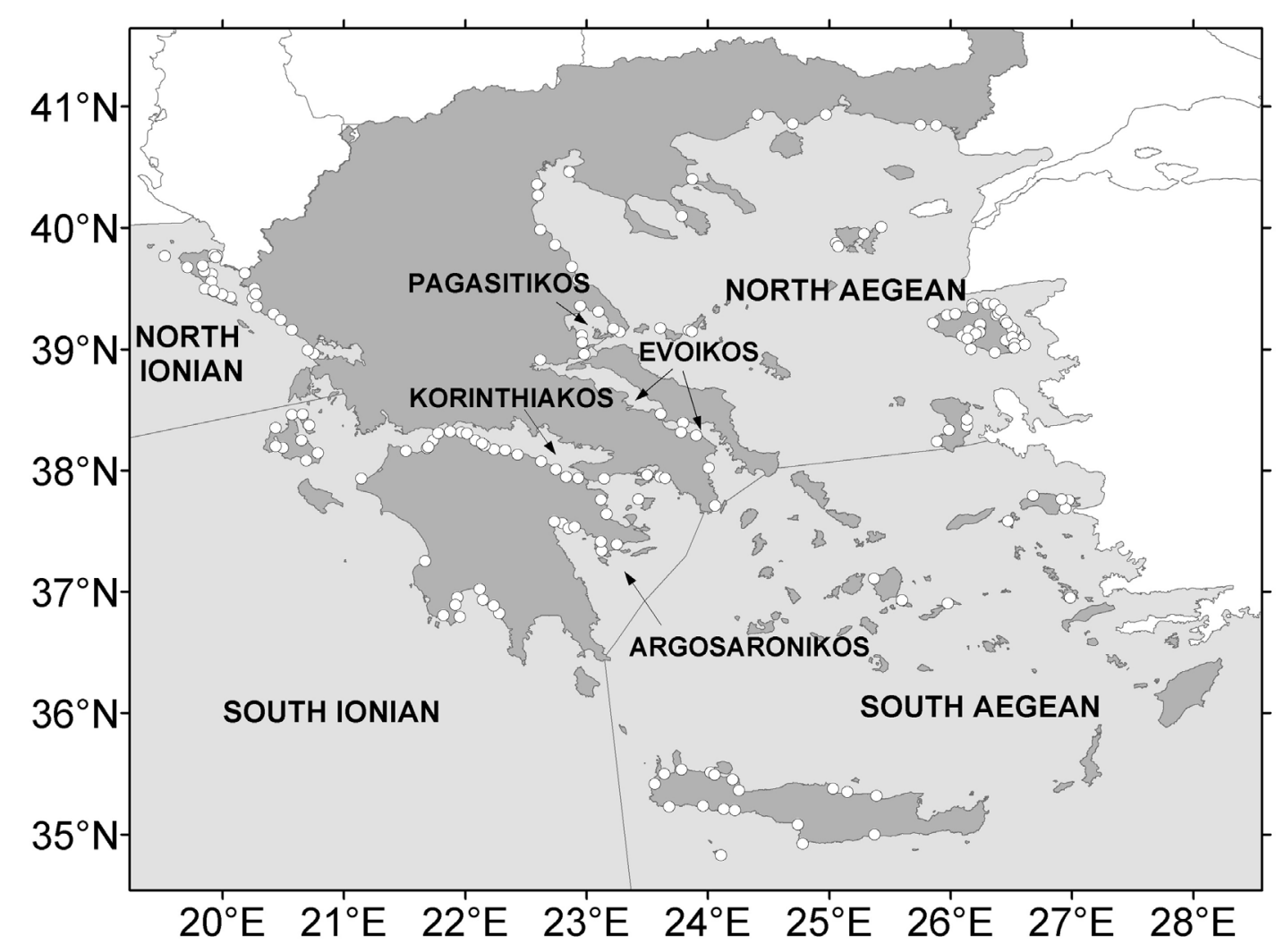

FIG. 1. - Map of Greece, with the main areas mentioned in the text. The sampling ports are marked with white bullets.

2007) have a boat seine license, of which 106 are registered in ports of the Ionian Sea and the rest are registered in the Aegean Sea. The number of vessels with a boat seine license has decreased by more than 30\% since 1991 (Fig. 2), as new licenses have not been issued since this period. The total capacity has also decreased in recent years (Fig. 2), while the average age $(\sim 43 \mathrm{yr})$ and length $(\sim 10 \mathrm{~m})$ of boat seines has remained roughly constant. The boat seine fleet

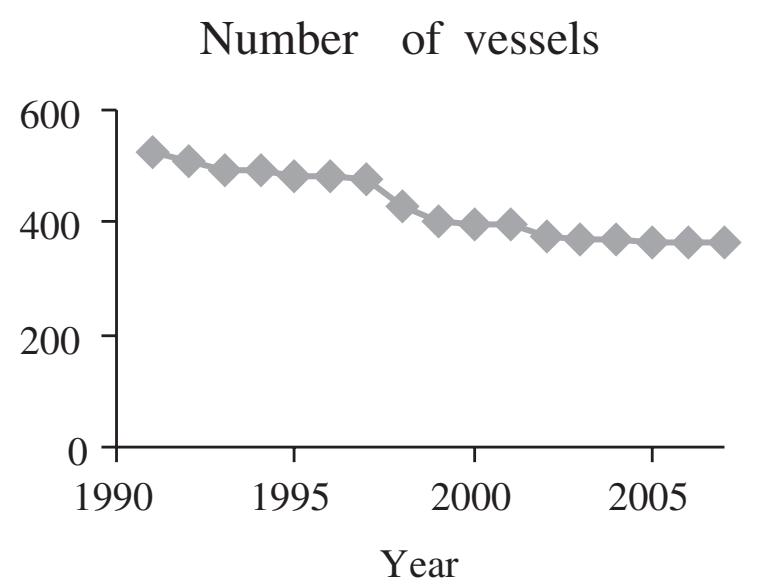

has the oldest vessels out of all the fleet segments in Greece.

Boat seines consist in a main body (or "shoulders'), two relatively long wings, the bag, and the cod-end. The total length of the net in Greek boat seines is usually between 200 and $450 \mathrm{~m}$. The wings constitute the longest part of the net; they have a length of 140 to $400 \mathrm{~m}$ and a stretched mesh size of 350 to $600 \mathrm{~mm}$. The bag, which is the central part

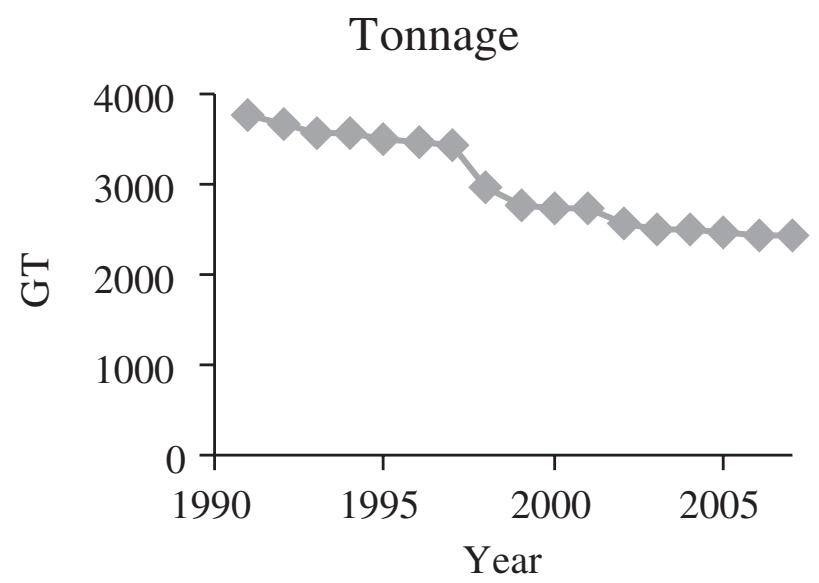

FIG. 2. - Time series of the number of vessels with a boat seine license in Greece and their total tonnage, from 1991 to 2007 (Source: IMASFish, 2008). 
of the net, is 13 to $40 \mathrm{~m}$ long with a stretched mesh size of 20 to $28 \mathrm{~mm}$. The rearmost part of the bag is the cod-end, which has a length of 1 to $7 \mathrm{~m}$; the netting of the cod-end usually has a stretched mesh size between 16 and $20 \mathrm{~mm}$ (Adamidou, 2007). Boat seines are used on the bottom, where they are hauled by two very long ropes extending from the wings. These ropes are an important component of the capture efficiency of boat seines, as they are used to encircle a large area and ensure that as many fish as possible are driven or herded towards the opening of the net. The ground rope is usually a fairly heavy rope weighted with lead rings, while the headline has oval and cylindrical floats.

An anchored buoy is initially set, from where the first hauling line is set, followed by the first wing, the bag, the second wing, and finally the second hauling rope, which goes back to the anchored buoy. In this way the whole gear encircles a large area in a more or less triangular pattern. When the vessel comes back to the anchor buoy, the first and second ropes are hauled in slowly and simultaneously using winches, and the fish are guided into the net; the hauling speed increases when the net is nearly closed.

The boat seine operates close to the coastline at depths usually between 10 and $50 \mathrm{~m}$ following more or less pre-defined hauls. Boat seines work on sandy, sandy/muddy bottoms or sea grass beds and they are most efficient on flat bottoms or areas with a small, smooth slope. According to the current legislation, fishing is allowed from one hour after sunrise to one hour before sunset. When hauling the gear onboard, the vessel must remain anchored and only operate the winches. The distance from the shore must be $<70 \mathrm{~m}$. There is a closure season for boat seines in Greece from April 1 until the end of September.

\section{Data}

Since 2002 data on effort and landings have been collected in Greece from 30 major sites, including 209 landing ports, in the framework of the Data Collection Regulation (EC 1543/2000; EC 1639/2001) (Fig. 1). From each site, species-specific landings data were gathered by local correspondents (most of which are Prefecture Fisheries Inspectors) on a monthly basis, according to a systematic sampling procedure. Specifically, each month the local correspondents visited a predefined number of landings ports in their site of responsibility and collected landings data of the arriving vessels. From this dataset (2002-2006), records of boat seine landings were used to identify landings profiles and potential métiers of the sector in the Aegean and Ionian Seas.

Only fishing trips with nonzero landings were considered, i.e. 1304 trips for the Aegean Sea and 737 trips for the Ionian Sea. Rare species, i.e. caught in less than $0.5 \%$ of the trips, were excluded from the analysis.

\section{Analysis}

The analysis was conducted separately for the Aegean and Ionian Seas because of the presence of different stocks of the same species in the two fairly distinct geographic areas. For each case, a data matrix A was built with fishing trips as individuals ( $n$ rows) and landings per species as variables ( $p$ columns). For each trip, the absolute weight of the landings was transformed into a landings profile, i.e. the relative species composition, by dividing the weight of the landings per species by the total weight of the landings of the fishing trip. This removed the differences in the level of the landings, which are often linked to factors such as the total effort, the time of the year, and the weather conditions. Data were then log-transformed to symmetrize their distribution. A modification of the multivariate approach proposed by Pelletier and Ferraris (2000) was used to identify potential métiers. The first step involved a factorial analysis of the log-transformed landings profiles, and the second step was a classification of the factorial coordinates.

Specifically, a non-normalized PCA (Principal Components Analysis) based on the covariance matrix was performed in order to describe the variation in the set of the $p$ correlated variables in terms of a new set of uncorrelated variables (principal components), each of which is a linear combination of the $p$ variables. The principal components are derived in decreasing order of importance in terms of their contribution to the total variation of the original data, and taken together explain all the variation. The general scope of PCA is that the first few components will account for a substantial proportion of the variation in the original variables and can be used to provide a convenient lower dimensional summary of these variables. Furthermore, PCA provides a geometric description of the individuals, the variables, and the relationships between them, which is helpful for exploring the structure of the 
dataset, and individuals are more easily allocated to a cluster through their factorial coordinates (Pelletier and Ferraris, 2000). The number of principal components selected was based on the scree diagram, which is a plot of the eigenvalues $\lambda_{i}$ of the covariance matrix against the rank $i$ of the eigenvalues. The number of components selected is the value of $i$ corresponding to an "elbow" in the curve, which is considered to be where "large" eigenvalues (i.e. accounting for a large proportion of the total variation of the original data) cease and "small" eigenvalues begin (e.g. Everitt, 2005).

A hierarchical agglomerative cluster (HAC) analysis, based on Euclidean distances and applying Ward's minimum variance criterion (Ward, 1963), was conducted using the retained principal components. The HAC analysis of the fishing trips identified homogenous groups (clusters) that represented different landings profiles. The choice of the number of clusters was based on expert knowledge and on several trials with different choices of dissimilarity threshold in the resulting dendrogram. Each of these clusters was considered to represent a potential métier.

PCA was conducted with the statistical package SPSS 13.0, while the HAC analysis was carried out with S-PLUS 6.2.

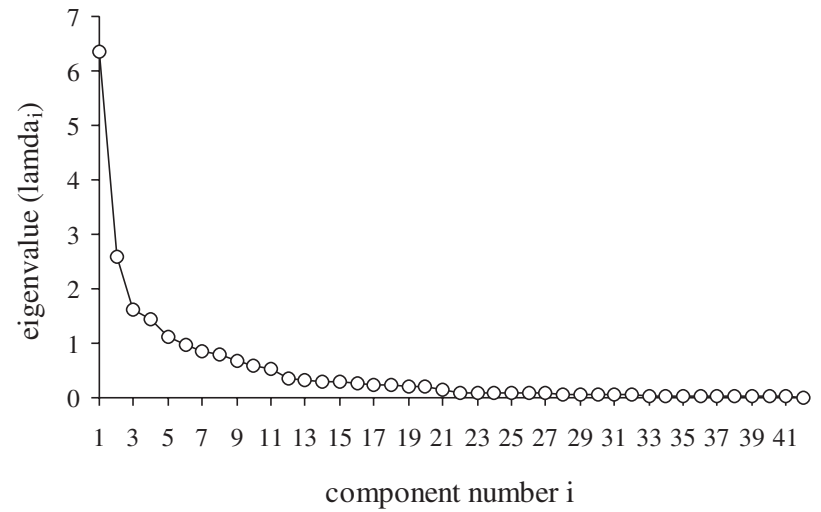

FIG. 3. - Scree diagram for the landings profile data matrix for boat seine fishing trips in the Aegean Sea.

\section{RESULTS}

A total of 62 species was recorded in the sample hauls in the Aegean Sea, of which 43 were retained in the analysis (after removing rare species). For the fishing trips in the Aegean Sea, seven principal components were retained based on the scree diagram and on the contribution of each component to the total variance (Fig. 3). These seven components accounted for $70 \%$ of the total variation of the original data. The HAC analysis of the fishing trips, based on the seven principal components, identified seven

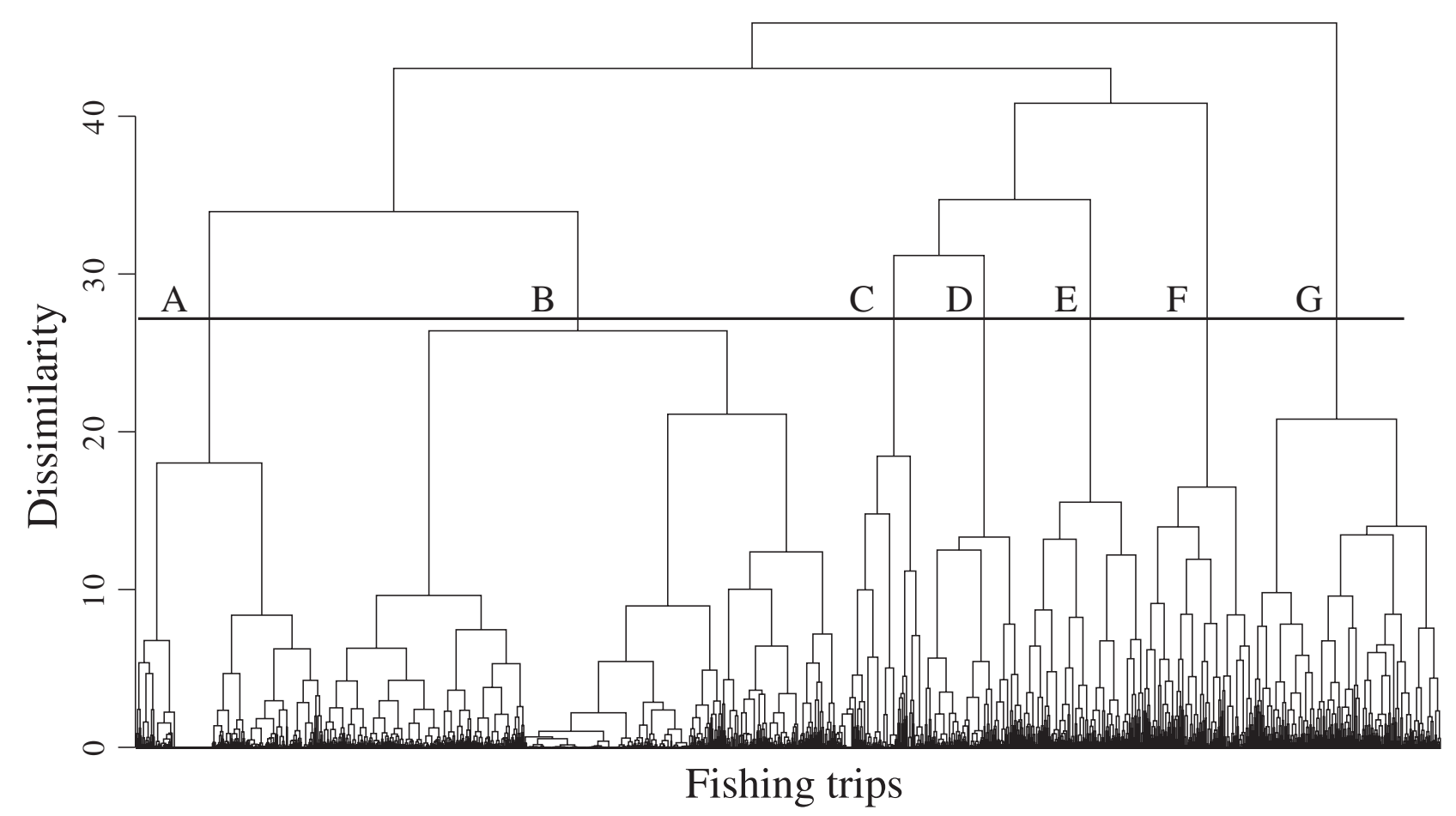

FIG. 4. - Dendrogram of the boat seine fishing trips in the Aegean Sea, based on the log-transformed landings profiles. 
TABLE 1. - Average landings profiles of the 7 clusters identified in the Aegean Sea (Fig. 4), given as the proportion (\%) of the landings of each species to the total landings of each cluster. The most important species of each profile (with a proportion in landings $>10 \%$ ) are given in bold.

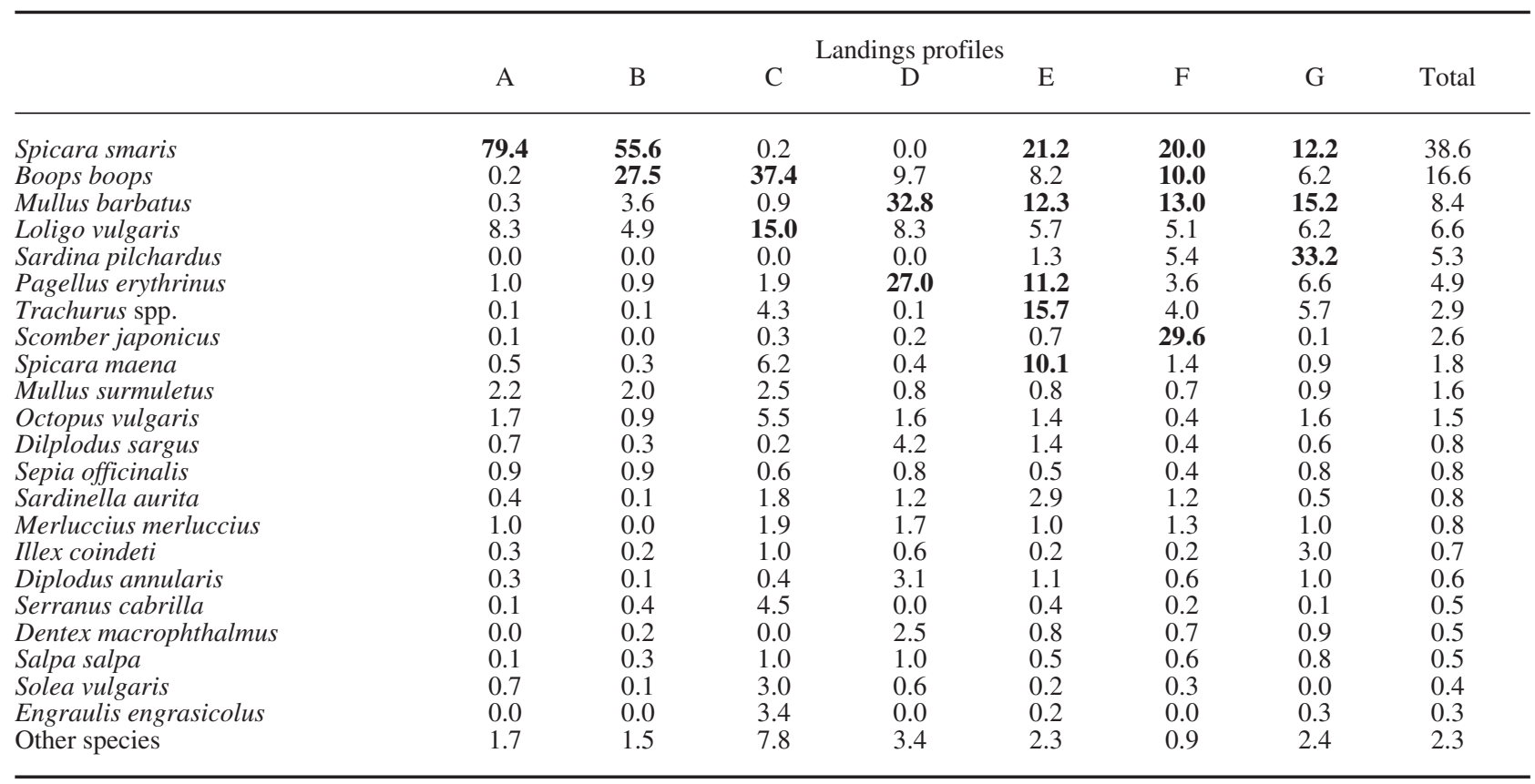

TABLE 2. - Percentage distribution of the recorded fishing trips of the seven boat seine identified landings profiles in each main geographical area of the Aegean Sea. For each area, the landings profiles with a contribution $>15 \%$ are given in bold.

Cluster Evvoikos Argosaronikos S Aegean N Aegean Pagassitikos

\begin{tabular}{lccccc}
\hline A & $\mathbf{2 2}$ & 12 & 14 & $\mathbf{1 7}$ & 0 \\
B & $\mathbf{4 7}$ & $\mathbf{2 6}$ & $\mathbf{6 3}$ & $\mathbf{3 2}$ & 0 \\
C & 7 & 1 & 11 & 14 & 0 \\
D & 7 & $\mathbf{1 6}$ & 1 & 2 & 0 \\
E & 2 & 13 & 1 & 6 & $\mathbf{8 9}$ \\
F & 3 & 12 & 7 & 9 & 9 \\
G & 13 & $\mathbf{2 0}$ & 3 & $\mathbf{2 1}$ & 3 \\
\hline
\end{tabular}

clusters $(A-G)$ that represented different landings profiles (Fig. 4).

These seven clusters had different average landings profiles (Table 1) and different geographical distributions among the 5 main sub-areas of the Aegean Sea (Table 2). In addition, there was a temporal pat-
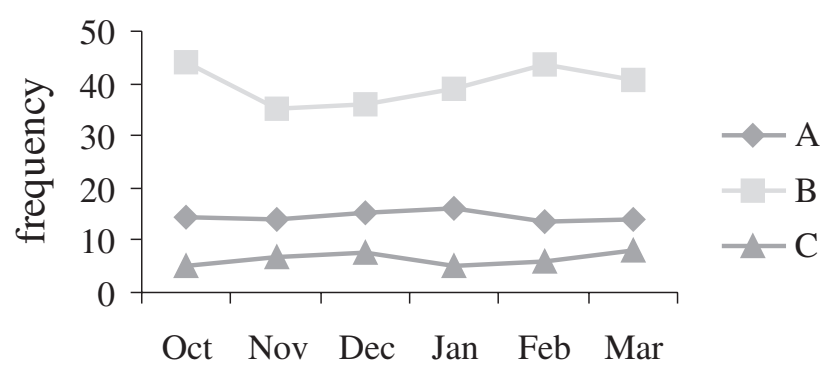

tern in the frequency of most landings profiles and a succession of landings profiles throughout the year (Fig. 5).

A total of 46 species was recorded in the sample hauls in the Ionian Sea, of which 27 were retained in the analysis (after removing rare species). For the fishing trips in the Ionian Sea, seven principal components were retained based on the scree diagram and on the contribution of each component to the total variance (Fig. 6). These seven components accounted for $73 \%$ of the total variation of the original data. The HAC analysis of the fishing trips based on the seven principal components identified four clusters ( $\mathrm{H}$ to $\mathrm{K}$ ) that represented different landings profiles (Fig. 7). The identified clusters had different landings profiles (Table 3) and different geographical distributions among the main sub-areas of the Ionian Sea (Table 4), and dissimilar temporal pat-

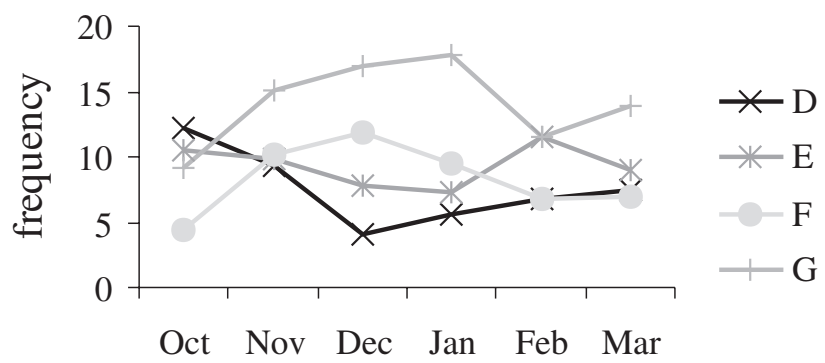

FIG. 5. - Monthly variation of the frequencies of occurrence of the identified landings profiles in the sample of fishing trips in the Aegean Sea. 


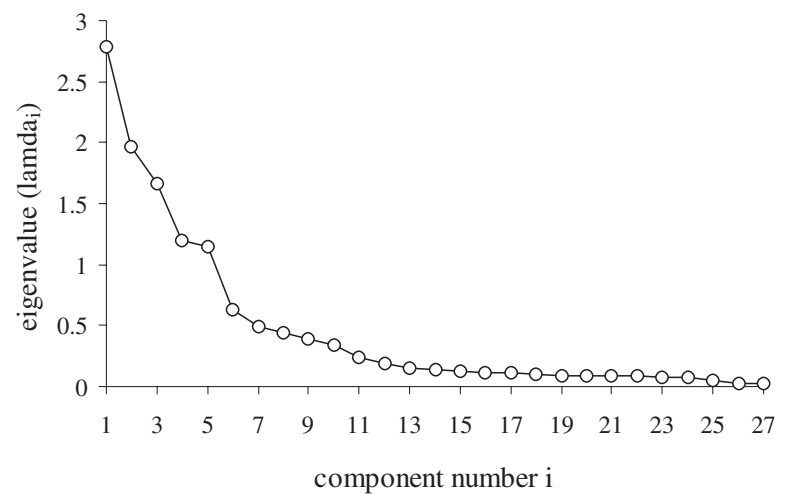

FIG. 6. - Scree diagram for the landings profile data matrix for boat seine fishing trips in the Ionian Sea.

terns in the frequency of the landings profiles were observed (Fig. 8).

In the Ionian Sea, just 5 species accounted for $90 \%$ of the landings (Table 3), while in the Aegean Sea more than ten species accounted for the same percentage (Table 1). Evidently in the Ionian Sea the boat seines seem to focus on less species than in the Aegean. Picarel is the primary target species of boat seines in both the Aegean and Ionian Seas, and is well represented in the catches of most identified métiers, except in C and D in the Aegean Sea, and I in the Ionian Sea.
TABLE 3. - Average landings profiles of the four clusters identified in the Ionian Sea (Fig. 6), given as the proportion (\%) of the landings of each species to the total landings of each cluster. The most important species of each profile (with a proportion in landings $>10 \%$ ) are given in bold.

\begin{tabular}{lccccc}
\hline & \multicolumn{5}{c}{ Landings profiles } \\
& $\mathrm{H}$ & $\mathrm{I}$ & $\mathrm{J}$ & $\mathrm{K}$ & Total \\
\hline Spicara smaris & $\mathbf{5 7 . 9}$ & 0.0 & $\mathbf{7 2 . 1}$ & $\mathbf{2 0 . 0}$ & 55.6 \\
Boops boops & $\mathbf{1 6 . 7}$ & $\mathbf{4 0 . 2}$ & 9.3 & $\mathbf{1 3 . 2}$ & 16.1 \\
Sardina pilchardus & 9.1 & $\mathbf{2 0 . 9}$ & 3.0 & $\mathbf{1 1 . 4}$ & 8.4 \\
Loligo vulgaris & 4.8 & $\mathbf{1 5 . 0}$ & 3.2 & 6.5 & 5.2 \\
Mullus barbatus & 3.6 & 8.7 & 4.6 & 5.6 & 4.3 \\
Spicara maena & 0.0 & 0.0 & 0.0 & $\mathbf{3 0 . 1}$ & 1.8 \\
Pagellus erythrinus & 0.1 & 1.6 & 5.6 & 1.0 & 1.6 \\
Salpa salpa & 1.4 & 0.0 & 0.2 & 3.0 & 1.1 \\
Sphyraena sphyraena & 0.8 & 2.7 & 0.4 & 2.3 & 0.9 \\
Sepia officinalis & 1.2 & 0.5 & 0.3 & 0.4 & 0.9 \\
Seriola dumerili & 0.6 & 1.9 & 0.0 & 1.3 & 0.6 \\
Trachurus spp. & 0.4 & 3.2 & 0.0 & 0.3 & 0.5 \\
Merluccius merluccius & 0.1 & 3.9 & 0.0 & 0.1 & 0.3 \\
Dilplodus sargus & 0.4 & 0.1 & 0.0 & 1.0 & 0.3 \\
Belone belone & 0.4 & 0.0 & 0.0 & 0.5 & 0.3 \\
Engraulis engrasicolus & 0.4 & 0.0 & 0.0 & 0.0 & 0.3 \\
Octopus vulgaris & 0.2 & 0.0 & 0.4 & 0.3 & 0.2 \\
Other species & 1.7 & 1.5 & 0.9 & 3.2 & 1.6 \\
& & & & & \\
\hline
\end{tabular}

The main characteristics of the identified boat seine landings profiles and potential métiers in both the Aegean and Ionian Seas are summarized in Table 5. The most frequent landings profiles observed were those targeting picarel and bogue (cluster B in the Aegean and $\mathrm{H}$ in the Ionian Sea) or picarel alone (cluster $\mathrm{A}$ in the Aegean and $\mathrm{J}$ in the Ionian Sea).

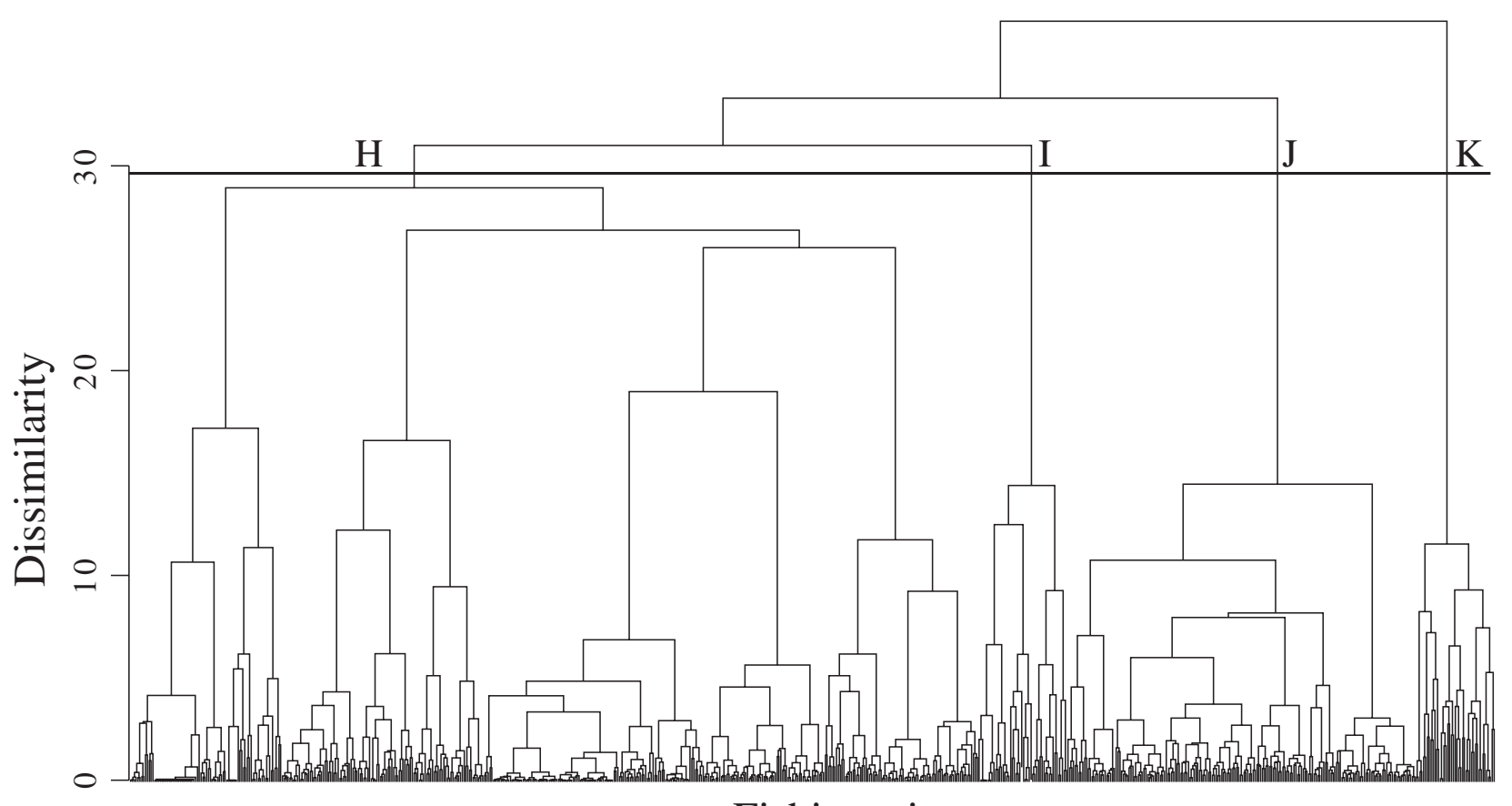

Fishing trips

FIG. 7. - Dendrogram of the boat seine fishing trips in the Ionian Sea, based on the log-transformed landings profiles. 
TABle 4. - Percentage distribution of the recorded fishing trips of the four identified boat seine landings profiles in each main geographical area of the Ionian Sea. For each area, the landings profiles with a contribution $>15 \%$ are given in bold.

\begin{tabular}{lccc}
\hline Cluster & C-S Ionian & Korinthiakos & N Ionian \\
\hline H & $\mathbf{5 3}$ & $\mathbf{6 9}$ & $\mathbf{9 1}$ \\
I & 6 & $\mathbf{2 2}$ & 1 \\
J & $\mathbf{3 6}$ & 0 & 0 \\
K & 5 & 9 & 8 \\
\hline
\end{tabular}

Landings profiles A and B as well as profiles $\mathrm{H}$ and $\mathrm{J}$ would be better combined into just two 'picarelbogue' métiers in the Aegean and Ionian Sea respectively, as their only substantial difference is in the presence of bogue in the catches. The absence of bogue in clusters $\mathrm{A}$ and $\mathrm{J}$ is due to chance rather than a different fishing strategy. These métiers are practiced all over the Aegean and Ionian Seas, with the exception of the Pagassitikos Gulf, and accounted for $54 \%$ and $88 \%$ respectively of the fishing trips of the sample. The stretched mesh size of the cod-end that is used when targeting picarel is the lowest legal

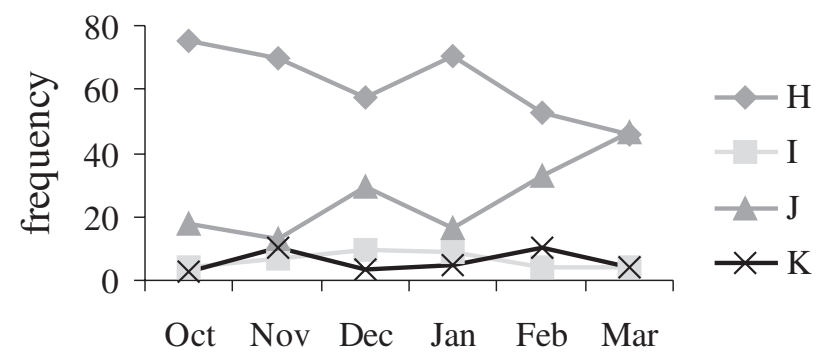

FIG. 8. - Monthly variation of the frequencies of occurrence of the identified landings profiles in the sample of fishing trips in the Ionian Sea.

size, i.e. $16 \mathrm{~mm}$, and the hauls are usually carried out over seagrass beds.

In Pagassitikos Gulf, a mixed métier (profile E) is practiced almost exclusively, which targets picarel, horse mackerels, red mullet, common pandora, and blotched picarel. Apart from Pagassitikos Gulf, this métier is also observed in the Argosaronikos area. Horse mackerels do not make up a substantial part of the landings in any other métier. The contribution of this métier to the total landings gradually decreases from the opening of the fishing season to reach a

TABLE 5. - Description of the identified boat seine landings profiles and potential métiers. Profiles A and B were combined with métier AEG$\mathrm{SV}-1$, and profiles $\mathrm{H}$ and $\mathrm{J}$ with métier ION-SV-1.

\begin{tabular}{|c|c|c|c|c|c|}
\hline Cluster & Cluster size & Profile characterization & Main species & \multicolumn{2}{|c|}{ Typical fishing locations Métier } \\
\hline \multicolumn{6}{|c|}{ Aegean Sea } \\
\hline A & 187 & Picarel & Spicara smaris $(79.4 \%)$ & \multirow{3}{*}{$\begin{array}{l}\text { all areas except } \\
\text { Pagassitikos } \\
\text { all areas except } \\
\text { Pagassitikos } \\
\mathrm{N} \text { and S Aegean }\end{array}$} & \multirow[t]{2}{*}{ AEG-SV-1 } \\
\hline B & 512 & Picarel - Bogue & Spicara smaris $(55.6 \%)$ & & \\
\hline $\mathrm{C}$ & 89 & Bogue - European squid & Boops boops $(37.4 \%)$ & & AEG-SV-2 \\
\hline $\mathrm{D}$ & 99 & \multirow{3}{*}{$\begin{array}{l}\text { Red mullet - } \\
\text { Common pandora } \\
\text { Mixed }\end{array}$} & $\begin{array}{l}\text { Lollgo vulgarls (15.0\%) } \\
\text { Mullus barbatus (32.8\%) }\end{array}$ & Argosaronikos & AEG-SV-3 \\
\hline $\mathrm{E}$ & 120 & & Spicara smaris (21.2\%) & \multirow{2}{*}{$\begin{array}{l}\text { Pagassitikos, } \\
\text { Argosaronikos }\end{array}$} & \multirow[t]{2}{*}{ AEG-SV-4 } \\
\hline $\mathrm{F}$ & 110 & & $\begin{array}{l}\text { Trachurus spp. }(15.7 \%) \\
\text { Mullus barbatus }(12.3 \%) \\
\text { Pagellus erythrinus }(11.2 \%) \\
\text { Spicara maena }(10.1 \%) \\
\text { Scomber japonicus }(29.6 \%) \\
\text { Spicara smaris }(20.0 \%) \\
\text { Mullus barbatus }(13.0 \%)\end{array}$ & & \\
\hline \multirow[t]{2}{*}{$\mathrm{G}$} & \multirow[t]{2}{*}{187} & \multirow{2}{*}{ European pilchard } & Sardina pilchardus (33.2\%) & \multirow[t]{2}{*}{$\begin{array}{l}\text { Argosaronikos, } \\
\mathrm{N} \text { Aegean }\end{array}$} & \multirow[t]{2}{*}{ AEG-SV-6 } \\
\hline & & & $\begin{array}{l}\text { Mullus barbatus }(15.2 \%) \\
\text { Spicara smaris }(22.2 \%)\end{array}$ & & \\
\hline $\mathrm{H}$ & & Picorel Rogur & & & \\
\hline $\mathrm{H}$ & 458 & Picarel - Bogue & $\begin{array}{l}\text { Splcara smarts }(1.7 \% \%) \\
\text { Boops boops }(16.7 \%)\end{array}$ & all areas & $10 N-S V-1$ \\
\hline $\begin{array}{l}\mathrm{J} \\
\mathrm{I}\end{array}$ & $\begin{array}{l}188 \\
48\end{array}$ & \multirow{2}{*}{$\begin{array}{l}\text { Picarel } \\
\text { Bogue - } \\
\text { European pilchard - } \\
\text { European squid } \\
\text { Mixed }\end{array}$} & $\begin{array}{l}\text { Spicara smaris }(72.1 \%) \\
\text { Boops boops }(40.2 \%) \\
\text { Sardina pilchardus }(20.9 \%) \\
\text { Loligo vulgaris }(15.0 \%)\end{array}$ & $\begin{array}{l}\text { C-S Ionian } \\
\text { Korinthiakos, } \\
\text { C-S Ionian }\end{array}$ & ION-SV-2 \\
\hline $\mathrm{K}$ & 43 & & $\begin{array}{l}\text { Spicara maena }(30.1 \%) \\
\text { Spicara smaris }(20.0 \%) \\
\text { Boops boops }(13.2 \%) \\
\text { Sardina pilchardus }(11.4 \%)\end{array}$ & all areas & ION-SV-3 \\
\hline
\end{tabular}




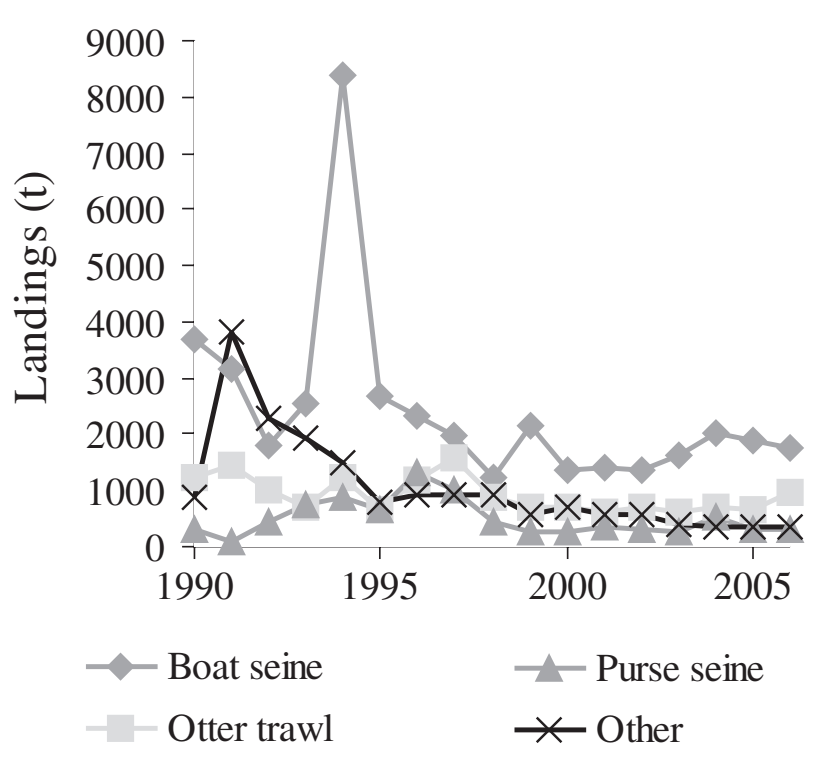

FIG. 9. - Time series of picarel landings by fishing gear, from 1990 to 2006 (Source: IMAS-Fish, 2008).

minimum in January, and then gradually increases to reach a peak in March.

One of the target species of boat seines is European squid, which is mostly caught by métier $\mathrm{C}$ in the Aegean Sea and métier I in the Ionian Sea but is also caught in smaller quantities in all other métiers. Although bogue comes first in landings (in terms of weight) in profiles $\mathrm{C}$ and $\mathrm{I}$ (and European pilchard in I), its market value is approximately one third of the value of squid; thus, in terms of revenue, European squid is the most important species in these profiles. When targeting European squid the fishermen often use a larger cod-end mesh size than when targeting picarel; a cod-end with a stretched mesh exceeding $20 \mathrm{~mm}$ may be used. They also conduct deeper hauls than when targeting picarel.

A métier targeting red mullet and common pandora (profile D) is observed mainly in the Argosaronikos area (Table 2). An essential difference of this métier from the others is that it targets benthic fish. The hauls are carried out in sandy/muddy areas and often a cod-end of a stretched mesh size $>16 \mathrm{~mm}$ is used. Both red mullet and common pandora have high market values. This métier makes its highest contribution to the landings during the opening of the boat seine season in October, reaches a minimum in December and gradually increases until the end of the fishing season. A similar métier was not observed in the Ionian Sea.

In profile $\mathrm{F}$, chub mackerel was the species with the largest percentage in landings. This profile was mostly observed in the Argosaronikos area but also in other areas of the Aegean Sea (Table 2). This métier was mostly observed between November and January (Fig. 5). A similar métier was not observed in the Ionian Sea, where chub mackerel was landed in insignificant quantities $(<0.2 \%$ of the sample landings).

The European pilchard is the main species landed in métier G, which is mostly fished between November and January (Fig. 5). The main areas of this métier are Argosaronikos and the north Aegean and to a lesser extent the Evvoikos Gulf (Table 2).

\section{DISCUSSION}

Boat seines generally follow pre-defined hauls, i.e. in each area there is a limited number of specific sites where boat seines usually fish. Generally, they keep using more or less the same sites for many years or decades. Depending on their target, the skippers choose a specific site and make the appropriate modifications to their gear, e.g. on the total length of the net and hauling ropes, and the mesh size of the cod-end. Métier choice is a trade-off between a combination of factors such as species abundance, market value, and accessibility of fishing grounds. The high abundance of picarel and its high demand, especially during the opening of the fishing season in October, are the main reasons for which picarel is the primary target species of boat seines. The boat seine is the main gear for picarel (Fig. 9), especially for small individuals, which are in greatest demand; small individuals $(0+$ age; $\sim 8 \mathrm{~cm}$ in length) are abundant in October and their abundance reduces progressively.

Red mullet, European squid, and common pandora have much higher market values (two to four times that of picarel), but their abundance and expected catch is much lower than that of picarel. In specific sites or in seasons of high abundance, it might be more profitable to shift to other métiers rather than target the main 'picarel-bogue' métier (AEG-SV-1 in the Aegean and ION-SV-1 in the Ionian Sea). For example, maturing European squid migrate inshore in relation to sea surface temperature and usually have two spawning peaks, a main one during November-December and a secondary one during early spring (Lefkaditou et al., 1998). When the abundance of squid increases in coastal areas, some boat seines apparently shift to metiers 
AEG-SV-2 and ION-SV-2 in the Aegean and the Ionian Sea respectively (Figs. 5 and 8; Lefkaditou $e t$ $a l ., 1998)$ to target high valued squid.

A landings profile may not strictly reflect the actual fisher's intentions but only approximate what was initially targeted and sometimes may even noticeably diverge from the targeted species. There is always uncertainty regarding the outcome of a fishing trip and there is no guarantee that the fisher's choices regarding the gear, the fishing ground, or the timing will have the anticipated result. Marchal (2008) conducted a comparative analysis of métiers and resulting landings profiles and found a fleet dependent linkage between them; in pelagic trawlers and gillnetters there was low uncertainty in forecasting métiers from landings profiles but high uncertainty was reported for bottom trawlers. Although in boat seines no such comparative analysis has been conducted, we would not expect a large discrepancy between the actual métiers and landings profiles. Boat seines generally operate in well established predefined hauls and the fishermen have a good knowledge of their fishing grounds. Thus, it is quite likely that the fishermen will reach their expectations.

A clear distinction between two landings profiles, i.e. two groups of target species, is not always easy as there is often a smooth transition between clusters and some trips may be equally attributed to two groups or may constitute an intermediate group. Defining the threshold in a cluster analysis of fishing trips in order to group the trips into homogenous clusters is not straightforward and may be variable both in time and space, as species assemblages vary according to the distribution and dynamics of stocks. Furthermore, more than one métier may be practiced in a single trip, which will probably result in intermediate landings profiles. In the absence of records of a haul level, landings profiles are an inexpensive (onboard surveys cost much more) and readily available (through the Data Collection Regulation) source of data for defining métiers. However, identifying métiers from landings profiles needs caution, and expert knowledge is often necessary to decide upon the final level of aggregation of the landings profiles.

Although landings profiles have been used extensively in the literature to define métiers, fisheries scientists have not agreed upon a unique multivariate method for métier definition. Lewy and Vinther (1994) applied a HAC analysis to identify Danish North Sea trawl fisheries, using the species composi- tion of the landings expressed as the fraction of the monetary value of each species to the total monetary value of the fishing trip. Clustering was based on the squared Euclidean distance and clusters were joined based on the centroid method. A similar approach but based on Ward's minimum variance criterion (Ward, 1963) was applied by Marchal (2008) for French demersal and pelagic métiers. He et al. (1997) used cluster analysis to identify longline sets and fishing strategies within the Hawaii-based fishery. They developed clusters in two steps: first a non-hierarchical cluster analysis ( $K$-mean method) was used to group all records into 2500 clusters, and second a HAC analysis based on Ward's minimum variance criterion (Ward, 1963) was applied to the 2500 clusters. Pelletier and Ferraris (2000) proposed a two-step approach for identifying métiers from landings data. In the first step, a factorial analysis was conducted in order to provide a reduced description of large datasets and to analyze relationships between variables, and in the second step, factorial coordinates were classified in order to construct clusters of individuals and characterize these clusters by explanatory variables. They used PCA, two-way correspondence analysis, and multiple correspondence analysis for the factorial analysis and HAC based on Ward's method (Ward, 1963) for the classification. In the second step, métiers were identified from both the species composition and the effort data by applying a multiple correspondence analysis (Senegal case study) or a two way correspondence analysis (Celtic Sea case study). Campos et al. (2007) defined landings profiles in the Portuguese bottom trawl fishery, based on HCA using Ward's method (Ward, 1963), and also conducted an independent PCA, keeping only the first two principal components.

Different conclusions may be reached depending on the multivariate approach, data transformation, dissimilarity measure and linkage type in cluster analysis, decision criteria for the choice of dissimilarity threshold in the resulting dendrogram, and other choices when fishing trip data are analyzed. Therefore, the métiers identified in this study were characterized as 'potential' in the sense that further verification based on carefully designed interviews with fishermen on a national scale, covering all local fisheries, would be desirable to finalize métier identification.

A previous study (Tzanatos et al., 2005) attempted to identify the main métiers of the small-scale fisheries in Greece, including boat seines (referred to 
as 'beach seine'), based on 227 questionnaires carried out at 9 of the 40 coastal prefectures of Greece. Just one métier was identified for boat seines, that of picarel, while red mullet and bogue were mentioned as 'not characterizing the beach seine métier'. This was probably due to a localized and relatively low sample size for boat seines. Stergiou et al. (1996), in a study of small-scale fisheries in the south Evvoikos Gulf, reported red mullet and bogue as the only species caught in relatively high quantities with either nets or boat seines and stressed the conflict between the two gears. The picarel catch reported by Stergiou et al. (1996) was quite low in relation to the catch of red mullet, bogue, and European pilchard. However, according to Stergiou et al. (2004) picarel was the target species for boat seines operating in the central Aegean. These differences among studies occur because of the area- and site-specific character of métiers and the great variations in target species among different areas, and even among fishermen's incentives of the same area. A large sample, welldistributed among all fishing areas, like the one used in this study, is advantageous for identifying all the main métiers on a national level.

There has been a long debate in the EU on the effects of boat seines on fish stocks and priority habitats such as posidonia beds. The fishing grounds of boat seines are often nursery grounds for many fish species, such as Pagellus erythrinus, Pagrus pagrus, Scorpaena spp., and Trachurus mediterraneus, and the catches of this gear often contain large quantities of juveniles, which are mostly discarded. Due to high induced mortality of undersized individuals of both commercial and non-commercial species, the boat seine has been banned from EU waters since 2001 (EU regulation 1626/1994). However, implementing the ban of boat seines in Greece has been prolonged until 2010 and some fishermen organizations are pressing for an exemption for Greece from this regulation beyond 2010, stating that the gear is much less destructive than is believed. A study on the outcome of boat seine closure on fish stocks proposed that this gear should not be banned but its management and the relevant regulations should be substantially changed (Petrakis et al., 2001). The main argument was that the closure of the gear would cause a market shortage of low-cost popular species like picarel, whose stocks are in a good state and are not targeted by other gears; thus, a low-cost protein resource would remain largely unexploited. However, an earlier study (Stergiou et al., 1996) revealed that beach seines were very effective in catching young and immature specimens and it was stated that "banning the beach seine could be essential for the conservation of demersal and inshore biodiversity". Further research (especially on the adverse effects of the boat seine on essential habitats and non-target species) is necessary to conclude if the boat seine sector may continue to operate sustainably in Greece under a different management scheme.

The present study represents the first attempt to identify boat seine métiers over such a wide area in the eastern Mediterranean. We believe that the current findings will contribute to a better understanding of the boat seine operation in Greece and will be useful for developing the necessary scientific advice and future management of the fisheries.

\section{ACKNOWLEDGEMENTS}

We thank Eugenia Lefkaditou for the Spanish translation of the Summary and two anonymous reviewers for their useful comments. This study was carried out with financial support from the Commission of the European Communities, the specific RTD programme "Specific Support to Policies", SSP-2006-044168-AFRAME. This paper does not necessarily reflect the programmes views and in no way anticipates the Commission's future policy in this area.

\section{REFERENCES}

Adamidou, A. - 2007. Commercial fishing gears and methods used in Hellas. In: C. Papaconstantinou, A. Zenetos, V. Vassilopoulou and G. Tserpes (eds.), State of Hellenic Fisheries, pp. 118131. Hellenic Centre for Marine Research, Athens.

Campos, A., P. Fonseca, T. Fonseca and J. Parente. - 2007. Definition of fleet components in the Portueguese bottom trawl fishery. Fish. Res., 83: 185-191.

Everitt, B. - 2005. An R And S-plus companion to multivariate analysis. Springer, London.

Gotsis-Skretas, O. and L. Ignatiades. - 2005. Phytoplankton in pelagic and coastal waters. In: E. Papathanassiou and A. Zenetos (eds.), State of the Hellenic marine environment, pp. 187-193. Hellenic Centre for Marine Research, Athens.

He, X., K.A. Bigelow and C.H. Boggs. - 1997. Cluster analysis of longline sets and fishing strategies within the Hawaii-based fishery. Fish. Res., 31: 147-158.

Hilborn, R. and M. Ledbetter. - 1985. Determinants of catching power in the British-Columbia salmon purse seine fleet. Can. J. Fish. Aquat. Sci., 42: 51-56.

IMAS-Fish. - 2008. Integrated database and GIS fisheries information system. Institute of Marine Biological Resources, Hellenic Centre for Marine Research. WWW electronic version: http:// amfitrion.ncmr.gr:7778/imasfish

Jimenez, M.P., I. Sobrino and F. Ramos. - 2004. Objective methods for defining mixed-species trawl fisheries in Spanish waters of the Gulf of Cadiz. Fish. Res., 67: 195-206. 
Lefkaditou, E., P. Sánchez, A. Tsangridis and A. Adamidou. - 1998. A preliminary investigation on how meteorological changes may affect beach-seine catches of Loligo vulgaris in the Thracean Sea (eastern Mediterranean). In: A.I.L. Payne, M.R. Lipiński, M.R. Clarke and M.A.C. Roeleveld (eds.), Cephalopod biodiversity, ecology and evolution. S. Afr. J. Mar. Sci. 20, pp. 453-461.

Lewy, P. and M. Vinther. - 1994. Identification of Danish NorthSea trawl fisheries. ICES J. Mar. Sci., 51: 263-272.

Marchal, P. - 2008. A comparative analysis of métiers and catch profiles for some French demersal and pelagic fleets. ICES J. Mar. Sci., 65: 674-686.

Marchal, P., B. Andersen, D. Bromley, A. Iriondo, S. Mahevas, F. Quirijns, B. Rackham, M. Santurtun, N. Tien and C. Ulrich. - 2006. Improving the definition of fishing effort for important European fleets by accounting for the skipper effect. Can. J. Fish. Aquat. Sci., 63: 510-533.

Maynou, F., M. Demestre and P. Sanchez. - 2003. Analysis of catch per unit effort by multivariate analysis and generalised linear models for deep-water crustacean fisheries off Barcelona (NW Mediterranean). Fish. Res., 65: 257-269.

Pech, N., A. Samba, L. Drapeau, R. Sabatier and F. Laloe. - 2001. Fitting a model of flexible multifleet-multispecies fisheries to Senegalese artisanal fishery data. Aquat. Living Resour., 14: 81-98.

Pelletier, D. and J. Ferraris. - 2000. A multivariate approach for defining fishing tactics from commercial catch and effort data. Can. J. Fish. Aquat. Sci., 57: 51-65.

Petrakis, G., A. Cheilari and S. Kavadas. - 2001. Evaluation of the consequences of the prohibition of the beach seine fishery in Greece. HCMR Technical report. Hellenic Centre for Marine Research, Athens.

Silva, L., J. Gil and I. Sobrino. - 2002. Definition of fleet components in the Spanish artisanal fishery of the Gulf of Cadiz (SW Spain ICES division IXa). Fish. Res., 59: 117-128.
Siokou-Frangou, I., E.D. Christou and N. Fragopoulou. - 2005. Zooplankton communities in the Hellenic Seas. In: E. Papathanassiou and A. Zenetos (eds.), State of the Hellenic marine environment, pp. 194-203. Hellenic Centre for Marine Research, Athens.

Stergiou, K.I., G. Petrakis and C.-. Politou. - 1996. Small-scale fisheries in the South Euboikos Gulf (Greece): species composition and gear competition. Fish. Res., 26: 325-336.

Stergiou, K.I., D.K. Moutopoulos and G. Krassas. - 2004. Body size overlap in industrial and artisanal fisheries for five commercial fish species in the Mediterranean Sea. Sci. Mar., 68: 179-188.

Tzanatos, E., E. Dimitriou, G. Katselis, M. Georgiadis and C. Koutsikopoulos. - 2005. Composition, temporal dynamics and regional characteristics of small-scale fisheries in Greece. Fish. Res., 73: 147-158.

Tzanatos, E., S. Somarakis, G. Tserpes and C. Koutsikopoulos. - 2006. Identifying and classifying small-scale fisheries métiers in the Mediterranean: A case study in the Patraikos Gulf, Greece. Fish. Res., 81: 158-168.

Ulrich, C. and B.S. Andersen. - 2004. Dynamics of fisheries, and the flexibility of vessel activity in Denmark between 1989 and 2001. ICES J. Mar. Sci., 61: 308-322.

Ulrich, C., D. Gascuel, M.R. Dunn, B. Le Gallic and C. Dintheer. -2001 . Estimation of technical interactions due to the competition for resource in a mixed-species fishery, and the typology of fleets and metiers in the English Channel. Aquat. Living Resour., 14: 267-281.

Vinther, M., S.A. Reeves and K.R. Patterson. - 2004. From singlespecies advice to mixed-species management: taking the next step. ICES J. Mar. Sci., 61: 1398-1409.

Ward, J.H. - 1963. Hierarchical grouping to optimize an objective function. J. Am. Stat. Assoc., 58: 236-244.

Scient. ed.: V.D. Valavanis.

Received January 26, 2009. Accepted March 26, 2009.

Published online November 19, 2009. 